\title{
THE EFFECT OF CAPITAL STRUCTURE, CORPORATE GOVERNANCE, LIQUIDITY AND FIRM SIZE ON FIRM VALUE WITH ROE AS INTERVENING VARIABLES
}

\author{
Faridhatun Faidah \\ Fakultas Ekonomi dan Bisnis Universitas Muria Kudus \\ faridhatun.faidah@umk.ac.id
}

\begin{abstract}
This research is aim to analyze the factors that affect value of firms with ROE as a mediation variable. Of 101 manufacture companies listed in Indonesian Stock Exchange during 2011-2015 period are used as sample in this research. By using panel data regression and path analysis it is found that ROE is mediating the effect of DER to firm value. However, the mediating effect of $R O E$ on institutional ownership, the current ratio and firm size to firm value are not founded. With this result it is suggested that to increase firm value companies should increase DER, institutional ownership and ROE.
\end{abstract}

Keywords: Capital Structure, Corporate Governance, Liquidity, Firm Size, ROE, Firm Value

\section{PENDAHULUAN}

Suatu perusahaan didirikan tidak hanya untuk meningkatkan profit semata namun juga dengan tujuan agar dapat menciptakan perusahaan yang bernilai tinggi. Peningkatan nilai dari perusahaan akan dapat memberikan kemakmuran yang lebih baik untuk para pemegang saham, sehingga usaha perusahaan untuk mempertinggi nilai dari perusahaanya menjadi hal yang sangat penting untuk diperhatikan. Cara yang dapat digunakan oleh perusahaan salah satunya adalah dengan mengambil keputusan yang tepat dalam hal manajemen keuangan. Keputusan tersebut terdiri dari penentuan investasi, pembagian deviden dan pemilihan pendanaan oleh perusahaan. Kolaborasi dari keputusan-keputusan manajamen keuangan tersebut apabila dilakukan dengan tepat maka akan dihasilkan proses manajemen dalam perusahaan yang terintegrasi untuk mewujudkan nilai perusahaan yang semakin meningkat.

Ang, (1997) menyatakan bahwa nilai perusahaan dapat diukur dengan salah satu indikator yang membandingkan harga saham terhadap nilai buku dari per lembar sahamnya atau yang yang disebut dengan Price To Book Value (PBV). Penggunaan PBV sebagai indikator dalam mengukur perusahaan ini dianggap lebih dapat menggambarkan nilai perusahaan karena perusahaan yang mempunyai laba negative dapat dinilai dengan menggunakan ukuran indikator PBV dan market value dapat lebih bisa digambarkan dengan ukuran yang lebih stabil dari nilai buku yang dimiliki oleh Price to Book Value (PBV). Selain itu, PBV juga dapat digunakan untuk menunjukkan under atau overvaluation di antara perusahaan yang sejenis dikarenakan standar akuntansi yang dimiliki PBV mempunyai standar akuntansi yang tetap bagi seluruh perusahaan, (Damodaran, 2001).

Nilai perusahaan dapat mengalami peningkatan karena harga sahamnya yang mengalami kenaikan. Salah satu penyebab dari naiknya nilai perusahaan adalah 
adanya kinerja dari perusahaan yang dianggap baik oleh masyarakat sehingga hal ini menjadi sinyal bagi para investor untuk lebih memilih menanamkan modalnya pada perusahaan tersebut. Permintaan yang tinggi dari masyarakat terhadap saham perusahaan inilah yang mengakibatkan harga saham menjadi naik dan selanjutnya juga akan menaikkan nilai dari perusahaan. Ukuran kinerja dari perusahaan dalam penelitian ini menggunakan Return on Equity (ROE), sesuai dengan penelitian yang dilakukan oleh Norhayati, et al (2012) yang menunjukkan adanya pengaruh positif kinerja keuangan (profitabilitas) terhadap nilai perusahaan sedangkan perbedaan hasil penelitian terdapat pada penelitian Tahir \& Razali (2011) yang menyatakan bahwa nilai perusahaan dipengaruhi secara negative oleh profitabilitas.

Salah satu fungsi dari manajemen keuangan yakni pendanaan mempunyai peran penting dalam mempengaruhi kinerja dari suatu perusahaan. Teori struktur modal menjelaskan bahwa kebijakan pendanaan perusahaan dalam menentukan struktur modal (bauran hutang dan ekuitas) bertujuan untuk mengoptimalkan nilai perusahaan. Hoque (2014) dalam penelitiannya menunjukkan adanya pengaruh yang positif dan signifikan dari DER terhadap nilai perusahaan. Sedangkan perbedaan hasil penelitian dating dari Loncan dan Caldeira (2014) yang menyatakan bahwa nilai perusahaan dipengaruhi secara negative oleh DER.

Pemakaian tata kelola perusahaan (Corporate Governance) di sebuah perusahaan menjadi alat untuk mengurangi terjadinya permasalahan antara pemilik perusahaan (principal) dengan pihak manajemen (agent) yang sering terjadi (Jensen dan Meckling, 1976). Corporate governance yang dikelola dengan baik ini diharapkan dapat membuat kinerja perusahaan menjadi semakin baik dan nantinya mampu menjadi stimulus dalam meningkatkan minat masyarakat dalam berinvestasi dan menjadikan perusahan memiliki nilai yang baik. Pengaruh corporate governance dalam mempengaruhi nilai perusahaan dibuktikan Filatotchev et al. (2011) dalam penelitiannya dimana corporate governance berpengaruh positif dalam meningkatkan nilai dari perusahaan. Penelitian ini didukung oleh Arouri et al (2014) yang juga menunjukkan bahwa corporate governance dalam hal ini diwakili oleh institusional ownership mampu meningkatkan nilai perusahaan. Selain itu pada penelitian Nuraina (2012) juga menunjukkan hasil yang berbeda dari penelitian sebelumnya dimana institusional ownership berpengaruh negative kepada nilai dari perusahaan.

Kemampuan perusahaan dalam melunasi hutang jangka pendeknya (likuiditas) merupakan salah satu factor penting yang juga memiliki dampak terhadap nilai perusahaan. Current Ratio (CR) adalah rasio yang dianggap paling tepat menurut Brigham \& Houston (2010) dalam menentukan kemampuan perusahaan dalam menutuh hutang jangka pendeknya dengan menggunakan aset lancarnya. Current Ratio (CR) yang terus mengalami kenaikan menjadi sinyal positif bagi investor karena perusahaan dianggap memiliki kelancaran dalam melunasi hutang-hutangnya. Kemudahan perusahaan dari segi likuiditas ini dapat membuat profitabilitas dari perusahaan juga ikut mengalami kenaikan. Pengaruh likuiditas yang diproksikan dengan Current Ratio (CR) terhadap nilai perusahaan ini didukung oleh penelitian Cheung et al (2015) yang menyatakan adanya pengaruh positif current ratio terhadap nilai perusahaan sedangkan hasil yang berlawanan ditunjukkan pada penelitian Sudiyatno et al (2012) dimana likuiditas mempunyai pengaruh yang negative terhadap nilai perusahaan.

Di samping struktur modal dan juga likuiditas dari perusahaan, factor lain yang juga berperan dalam meningkatkan nilai perusahaan yaitu ukuran dari perusahaan 
itu sendiri. Perusahaan dengan ukuran besar dalam hal ini dilihat dari total asetnya diharapkan akan lebih memudahkan pihak manajemen dalam pengembangan usaha dan juga pencarian tambahan modal di pasar modal. Peningkatan total aktiva yang semakin tinggi di perusahaan akan memberikan output operasi yang bertambah tinggi pula, sehingga dari sini akan menimbulkan citra yang baik di masyarakat terhadap perusahaan. Pengaruh ukuran perusahaan dalam meningkatkan kinerja dari perusahaan dibuktikan oleh Putu et al (2014) yang menyatakan bahwa kinerja perusahaan dipengaruhi secara positif oleh ukuran perusahaan sedangkan Cheung et al. (2015) memberikan hasil yang berbeda dimana ukuran perusahaan memberikan pengaruh yang negative kepada nilai perusahaan.
(DER), institusional ownership, likuiditas (CR) dan ukuran perusahaan, kepada Return on Equity (ROE) dan pengaruhnya terhadap Nilai dari perusahaan dan dampaknya terhadap nilai perusahaan menunjukkan hasil yang berbeda dan tidak konsisten sehingga terjadi research gap. Fenomena gap dan research gap tersebut menjadi alasan untuk melakukan penelitian lebih lanjut mengenai faktor-faktor yang mempengaruhi nilai perusahaan. Penelitian ini dilakukan untuk menguji pengaruh variabel Debt to Equity Ratio (DER), institusional ownership, likuiditas (CR) dan ukuran perusahaan terhadap Nilai perusahaan dengan menggunakan Return on Equity (ROE) sebagai variabel mediasi. Pengamatan dilakukan pada perusahaan manufaktur yang terdaftar di BEI mulai tahun 2011 sampai 2015.

Tabel 1

Rata-Rata Nilai DER, Kepemilikan Institusional, Current Ratio, Ukuran Perusahaan, ROE dan Nilai Perusahaan Manufaktur pada Tahun 2011-2015

\begin{tabular}{|l|c|c|c|c|c|}
\hline \multirow{2}{*}{ Rasio } & \multicolumn{5}{c|}{ Tahun } \\
\cline { 2 - 6 } & 2011 & 2012 & 2013 & 2014 & 2015 \\
\hline DER (x) & 1,27 & 1.45 & 2,22 & 0,99 & 1,90 \\
\hline Kepemilikan Institusional (\%) & 72,86 & 72,48 & 71,91 & 72,95 & 72,62 \\
\hline Current Ratio (x) & 2,26 & 2,40 & 4,53 & 6,80 & 2,13 \\
\hline Size (Ln Total Aset) & 14,12 & 14,34 & 14,53 & 14,60 & 28,00 \\
\hline ROE (\%) & 13,27 & 12,82 & 8,50 & 14,12 & 7,26 \\
\hline PBV (x) & 2,99 & 3,22 & 2,86 & 2,36 & 2,52 \\
\hline
\end{tabular}

Sumber : Data ICMD dan laporan keuangan tahun 2011-2015 yang telah diolah

Selama periode pengamatan tahun 20112015 pada perusahaan manufaktur yang terdaftar pada Bursa Efek Indonesia dapat diketahui bahwa perubahan nilai Debt to Equity Ratio (DER), institusional ownership, likuiditas (CR), ukuran perusahaan, Return on Equity (ROE) dan Nilai perusahaan tidak seragam. Hal ini menunjukkan adanya fenomena gap pada perusahaan manufaktur di Indonesia. Penelitian terdahulu mengenai hubungan variabel Debt to Equity Ratio

\section{KAJIAN PUSTAKA}

Jenis data yang digunakan dalam penelitian ini adalah data kuantitatif. Sumber data pada penelitian ini adalah data sekunder yang diperoleh dari ICMD dan laporan keuangan perusahaan Manufaktur yang terdaftar di BEI periode tahun 2011-2015. Dimana pada tahun tersebut perekonomian indonesia relatif stabil namun ditemukan adanya ketidakkonsistenan arah hubungan dari antar variabel penelitian, sehingga 
perlu dilakukan penelitian kembali terkait variabel-variabel yang mempengaruhi Nilai Perusahaan. Data yang sudah diperoleh akan dianalisis dengan menggunakan bantuan software Eviews 9 .

Populasi yang dipakai pada penelitian ini adalah perusahaan Manufaktur yang tercantum di BEl sedangkan untuk sampel digunakan teknik purposive sampling, yaitu dengan cara penulis mensyaratkan ketentuan-ketentuan yang wajib dimiliki sebagai berikut : a. Perusahaan Manufaktur yang tercantum di Bursa Efek Indonesia secara tetap selama lima tahun yaitu dari tahun 2011 sampai 2015 dan belum pernah dikeluarkan dari Bursa Efek Indonesia. b. Perusahaan menerbitkan laporan keuangan yang berisi lengkap data yang diperlukan pada penelitian ini yaitu selama periode 2011-2015 berisi data Debt to Equity Ratio (DER), Current Ratio (CR), Institusional Ownership, Ukuran perusahaan, Return on Equity (ROE) dan Price Book to Value (PBV). Variabel yang digunakan dalam penelitian ini dijelaskan dengan Tabel 2.

\section{Metode Penelitian}

Analisis data yang dilakukan dalam penelitian ini adalah analisis kuantitatif dimana teknik analisisnya dibantu dengan

Tabel 2. Variabel Penelitian

\begin{tabular}{|c|c|c|c|}
\hline VARIABEL & DEFINISI & SKALA & $\begin{array}{c}\text { RUMUS PENGUKURAN } \\
\text { (SUMBER) }\end{array}$ \\
\hline \multicolumn{4}{|c|}{ VARIABEL DEPENDEN } \\
\hline $\begin{array}{l}\text { Price to Book } \\
\text { Value Ratio } \\
\text { (PBV) }\end{array}$ & $\begin{array}{l}\text { Perbandingan harga } \\
\text { saham penutupan pada } \\
\text { setiap akhir periode } \\
\text { terhadap jumlah ekuitas } \\
\text { per lembar saham }\end{array}$ & Rasio & $\begin{array}{r}P B V=\frac{\text { Closing share Price }}{\text { equity per share }} \\
\text { (Mahdaleta et al, 2016) }\end{array}$ \\
\hline \multicolumn{4}{|c|}{ VARIABEL INTERVENING } \\
\hline $\begin{array}{l}\text { Return On Equity } \\
\text { (ROE) }\end{array}$ & $\begin{array}{l}\text { Perbandingan antara } \\
\text { laba bersih perusahaan } \\
\text { dengan ekuitas yang } \\
\text { dimiliki oleh perusahaan }\end{array}$ & Rasio & $\begin{array}{c}R O E=\frac{\text { EAT }}{\text { Total Equity }} \\
\text { (Delen et al, 2013) }\end{array}$ \\
\hline
\end{tabular}

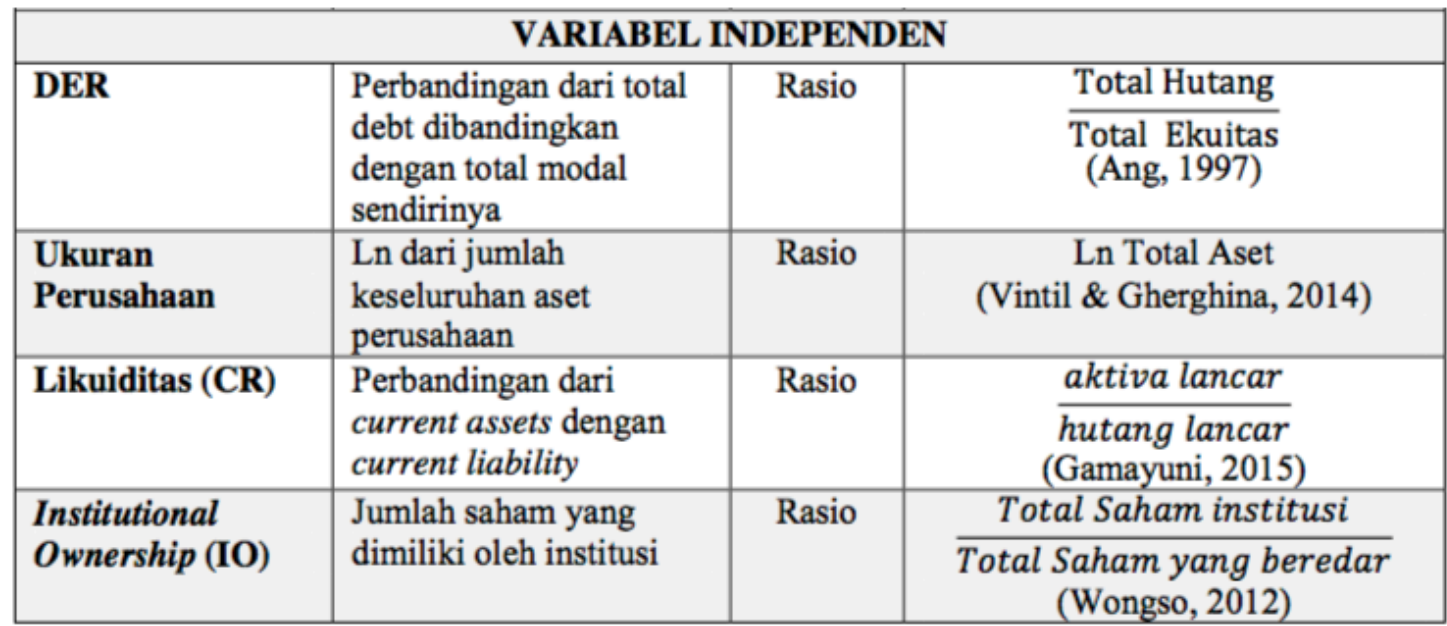

Sumber : Mahdaleta et al (2016), Delen et al (2013), Ang (1997), Vintil \& Gherghina (2014), Gamayuni, (2015) dan Wongso, (2012) 
software aplikasi data bernama Eviews 9. Jenis data yang digunakan adalah data panel (pooled data). Metode analisis data yang dipakai pada penelitian ini dengan cara menggunakan proses pemilihan model yaitu pertama dengan melakukan estimasi regresi data panel, baru setelah dipilih model terbaik akan dilakukan pengujian terhadap hipotesis dan terakhir menggunakan path analysis untuk melihat pengaruh variable yang memediasi.

Dalam penelitian ini tidak digunakan uji asumsi klasik karena menurut Gujarati, (2012:237) penggunaan teknik estimasi data panel sudah memiliki kelebihan tersendiri, yang diantaranya adalah sudah dapat mengatasi adanya masalah heterogenitas dan multikolonieritas. Selain
Persamaan kedua :

$$
\beta_{4} \ln \operatorname{SIZE}+e_{1}
$$

$$
\begin{gathered}
\mathrm{PBV}=\alpha_{1}+\beta_{5} \mathrm{DER}+\beta_{6} \mathrm{INST}+\beta_{7} \mathrm{CR}+ \\
\beta_{8} \ln \mathrm{ln} I \mathrm{EE}+\beta_{9} \mathrm{ROE}+\mathrm{e}_{2}
\end{gathered}
$$

\section{HASIL PENELITIAN \\ Pemilihan Model Estimasi Regresi Data Panel 1. Common Effect dan Fixed Effect (Chow Test)}

Chow Test dipakai dalam penilaian pertama yang diujikan untuk memilih model fixed effect atau common effect yang terpilih untuk dapat dipakai dalam memprediksi data panel. Hasil Chow Test pada fungsi persamaan yang pertama dapat dilihat pada tabel 3.

Dari hasil output pata tabel 3 di atas, dapat dilihat probability untuk cross- section

Tabel 3

Hasil Chow Test Persamaan 1

Redundant Fixed Effects Tests

Equation: Untitled

Test cross-section fixed effects

\begin{tabular}{lrrr}
\hline \hline Effects Test & Statistic & d.f. & Prob. \\
\hline \hline Cross-section F & 8.466155 & $(96,346)$ & 0.0000 \\
Cross-section Chi-square & 540.270602 & 96 & 0.0000 \\
\hline \hline
\end{tabular}

Sumber : Output Eviews 9, data diolah, 2016

Tabel 4

Hasil Chow Test Persamaan 2

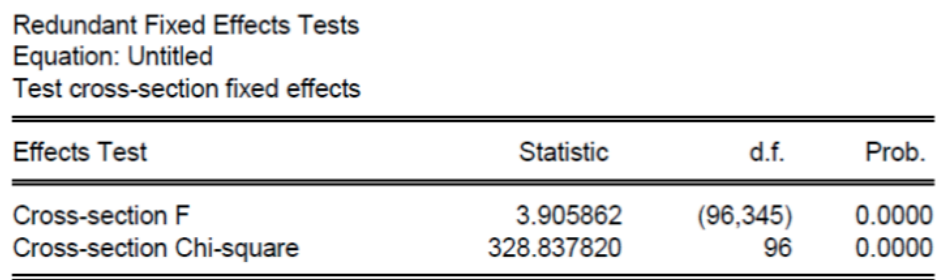

Sumber : Output Eviews 9, data diolah, 2016

itu dengan penggunaan regresi data panel juga dapat meminimalkan timbulnya bias yang kemungkinan terjadi selama proses penelitian dilakukan.

Fungsi regresi dalam penelitian ini dapat dituliskan menjadi 2 fungsi persamaan yaitu (Ghozali, 2011) :

Persamaan pertama :

ROE $=\alpha_{1}+\beta_{1}$ DER $+\beta_{2}$ INST $+\beta_{3}$ CR +
F pada persamaan 1 adalah sebesar 0,0000 lebih kecil dari 0,05 , sehingga model terbaik yang dipilih yaitu fixed effect model. Sedangkan untuk persamaan 2 hasilnya pada tabel 4 di atas, dapat dilihat probability untuk cross- section $\mathrm{F}$ pada persamaan 2 adalah sebesar 0,0000 lebih kecil dari 0,05, sehingga model terbaik yang dipilih yaitu fixed effect model. 


\section{Fixed Effect Vs Random Effect (Hausmant Test)}

Hausmant Test digunakan dalam penelitian ini sesudah terpilih fixed effect

model dari hasil uji chow test. Pengujian statistik Hausman memakai distribusi chisquare. Jika hipotesis nol diterima maka model terbaik yang tepat digunakan adalah random effect model, namun jika hipotesis nol ditolak maka dapat disimpulkan bahwa kecil dari alpha 0,05 sehingga model yang tepat untuk digunakan pada persamaan 2 dalam penelitian ini adalah tetap fixed effect model.

\section{Koefisien Determinasi}

Di bawah adalah ini hasil dari perhitungan koefisien determinasi (R2) pada persamaan 1 dan 2.

Nilai adjusted $R$ square sebesar 0,623

Tabel 5

Hasil Hausmant Test Persamaan 1

Correlated Random Effects - Hausman Test

Equation: Untitled

Test cross-section random effects

\begin{tabular}{lrrr}
\hline \hline Test Summary & $\begin{array}{c}\text { Chi-Sq. } \\
\text { Statistic }\end{array}$ & Chi-Sq. d.f. & Prob. \\
\hline \hline Cross-section random & 97.522936 & 4 & 0.0000 \\
\hline \hline
\end{tabular}

Sumber : Output Eviews 9, data diolah, 2016

Tabel 6

Hasil Hausmant Test Persamaan 1

Correlated Random Effects - Hausman Test

Equation: Untitled

Test cross-section random effects

\begin{tabular}{lrrr}
\hline \hline Test Summary & $\begin{array}{r}\text { Chi-Sq. } \\
\text { Statistic }\end{array}$ & Chi-Sq. d.f. & Prob. \\
\hline \hline Cross-section random & 11.303229 & 5 & 0.0457 \\
\hline \hline
\end{tabular}

Sumber : Output Eviews 9, data diolah, 2016

random effect model tidak tepat digunakan sehingga tetap digunakan fixed effect model.

Dari hasil output pada tabel 5 dapat dilihat probability adalah sebesar 0,000 lebih kecil dari alpha 0,05 sehingga model yang tepat untuk persamaan 1 dalam penelitian ini tetap menggunakan fixed effect model. Sedangkan untuk persamaan 2 hasilnya adalah sebagai berikut :

Dari hasil output pada tabel 6 dapat dilihat probability adalah sebesar 0,04 lebih untuk variabel dependent ROE menunjukkan bahwa variasi variabel independent mampu menjelaskan $62,3 \%$ variasi variabel dependent, sedangkan sisanya yaitu sebesar $37,2 \%$ dijelaskan oleh variabel lain diluar variabel independent. Nilai adjusted $R$ square sebesar 0,436 untuk variabel dependent PBV menunjukkan bahwa variasi variabel independent mampu menjelaskan $43,6 \%$ variasi variabel dependent, sedangkan sisanya yaitu sebesar $56,4 \%$

persamaan 1 dan 2

\begin{tabular}{|} 
Tabel 7. Koefisien Determinasi \\
\begin{tabular}{|c|c|c|}
\hline Variabel Dependent & R Square & Adjusted R Square \\
\hline ROE & 0,707 & 0,623 \\
\hline PBV & 0,564 & 0,436 \\
\hline
\end{tabular}
\end{tabular}

Sumber : Output analisis data 


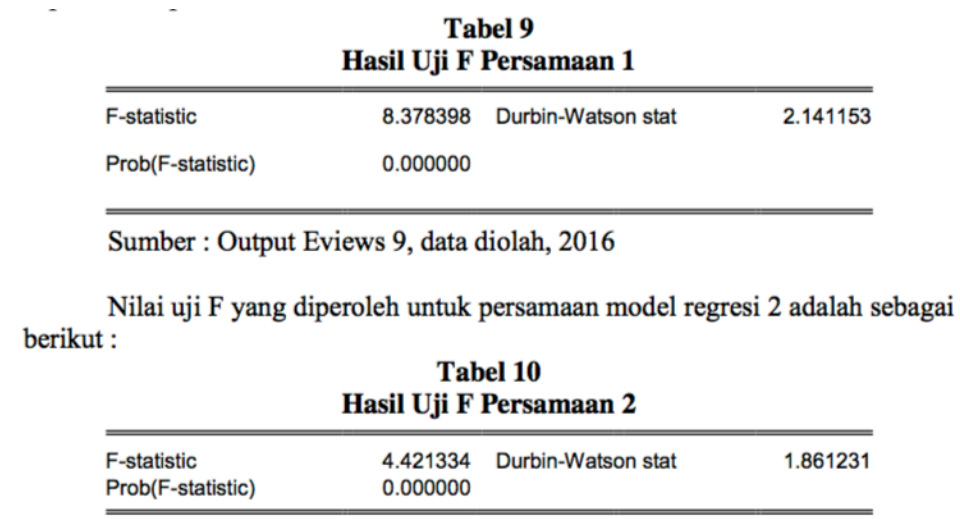

Sumber : Output Eviews 9, data diolah, 2016

dijelaskan oleh variabel lain di luar variabel independen. Hasil nilai yang diperoleh dari koefisien determinasi pada tabel di atas menunjukkan bahwa dua model struktural dianggap cukup baik (moderat) dikarenakan $\mathrm{R}$-square yang dihasilkan mempunyai nilai di atas 0,33 yang menyebabkan kedua model regresi yang diusulkan menjadi layak untuk diteliti.

\section{Uji Signifikansi Simultan (Uji F)}

Uji $F$ menunjukkan makna dari persamaan regresi yang sudah diuji dengan cara simultan atau bersama-sama. Dalam pengujian ini akan diperoleh hasil yang menunjukkan apakah ada pengaruh secara bersama-sama dari variable independen kepada variable dependen atau sebaliknya tidak ditemukan pengaruh. Hasil pengujian simultan yang dihasilkan pada persamaan 1 dan 2 pada penelitian ini dapat dilihat pada tabel 9 .
Dari tabel 9 dan tabel 10 di atas menunjukkan pada persamaan 1 model regresi memiliki nilai $F$ sebesar 8,378398 dengan signifikansi sebesar 0,000000 dan persamaan 2 model regresi memiliki nilai F sebesar 4.421334 dengan signifikansi sebesar 0,000000. Hal ini menunjukkan bahwa model regresi 1 dan 2 memberikan arti bahwa variabel independen secara serentak atau bersama-sama dapat mempengaruhi ROE pada persamaan 1 dan PBV pada persamaan 2 .

\section{Uji Signifikansi Partial (Uji t)}

Uji t ini diujikan guna mengetahui tingkat signifikansi secara parsial atau di bawah ini adalah hasil pengujian signifikansi partial (uji t) pada persamaan model regresi pertama.

Berdasarkan hasil perhitungan pada tabel $11 \mathrm{di}$ atas, dapat dilihat bahwa

variabel DER memiliki pengaruh positif signifikan terhadap ROE dan KEPINST

Tabel 11

Hasil Fixed Effect Model pada Persamaan 1

Dependent Variable: ROE

Method: Panel Least Squares

Sample: 20112015

Periods included: 5

Total panel (unbalanced) observations: 447

\begin{tabular}{crrrr}
\hline \hline Variable & \multicolumn{1}{c}{ Coefficient } & \multicolumn{1}{l}{ Std. Error } & \multicolumn{1}{c}{ t-Statistic } & Prob. \\
\hline \hline DER & 0.470992 & 0.073312 & 6.424442 & 0.0000 \\
KEPINST & -0.086980 & 0.041566 & -2.092583 & 0.0371 \\
CR & 0.535260 & 0.363680 & 1.471791 & 0.1420 \\
LNSIZE & -0.101184 & 0.067101 & -1.507933 & 0.1325 \\
C & 17.03641 & 3.238328 & 5.260866 & 0.0000 \\
\hline \hline
\end{tabular}

Sumber : Output Eviews 9, data diolah, 2016 
Tabel 12

Hasil Fixed Effect Model pada Persamaan 2

Dependent Variable: PBV

Method: Panel Least Squares

Sample: 20112015

Periods included: 5

Cross-sections included: 97

Total panel (unbalanced) observations: 447

\begin{tabular}{crrrr}
\hline \hline Variable & Coefficient & Std. Error & t-Statistic & Prob. \\
\hline \hline DER & -0.176844 & 0.075730 & -2.335180 & 0.0201 \\
KEPINST & 0.058802 & 0.022786 & 2.580616 & 0.0103 \\
CR & 0.038885 & 0.059434 & 0.654262 & 0.5134 \\
LNSIZE & 0.019517 & 0.010968 & 1.779522 & 0.0760 \\
ROE_ESTIM & 9.776176 & 3.188274 & 3.066291 & 0.0023 \\
C & -26.34093 & 9.211979 & -2.859422 & 0.0045 \\
\hline \hline
\end{tabular}

Sumber : Output Eviews 9, data diolah, 2016

memiliki pengaruh negatif signifikan terhadap ROE. Sedangkan pada variabel CR dan LNSIZE tidak memiliki pengaruh yang signifikan terhadap ROE, sehingga bentuk persamaan regresi pertama dengan menggunakan fixed effect model dapat dituliskan sebagai berikut :

$$
\begin{gathered}
\text { ROE }=17,03641+0.470992 \text { DER }- \\
0,086980 \text { KEPINST }+0,535260 \text { CR } \\
-0,101184 \text { LNSIZE }
\end{gathered}
$$

Hasil pengujian hipotesis secara individual (uji t) pada persamaan model regresi yang kedua dapat dilihat pada tabel 12.

Berdasarkan hasil perhitungan pada tabel 12 di atas, dapat diperoleh hasil penelitian bahwa berpengaruh negatif signifikan terhadap PBV sedangkan untuk KEPINST dan ROE_ESTIM berpengaruh positif terhadap PBV. Variabel $\mathrm{CR}$ dan LNSIZE tidak memiliki pengaruh terhadap PBV, sehingga berdasarkan hasil tersebut bentuk persamaan model regresi kedua dengan menggunakan fixed effect model dapat dituliskan sebagai berikut :

$$
\begin{gathered}
\text { PBV }=-26,34093-0.176844 \text { DER }+ \\
\text { 0.058802KEPINST + 0.038885CR + } \\
\text { 0.019517LNSIZE + 9.776176ROE_ESTIM }
\end{gathered}
$$

\section{Analisis Jalur}

Hasil analisis jalur (path analysis) data dapat disajikan dalam bentuk Tabel 13.Pada hasil perhitungan analisis jalur di atas dapat dilihat bahwa pengaruh tidak langsung lebih besar dibandingkan pengaruh langsung hanya terdapat pada variabel DER dan CR, sehingga dapat disimpulkan ROE hanya mampu memediasi pengaruh dari variabel DER dan CR terhadap PBV.

Mediasi variabel intervening pada pengaruh variabel independent terhadap variabel dependent Gambar 1. Pengujian mediasi dilakukan dengan mengunakan sobel test dan diperoleh hasil pada Tabel 13.

Tabel 13

Hasil Analisis Jalur

\begin{tabular}{|l|c|c|c|}
\hline \multicolumn{1}{|c|}{$\begin{array}{c}\text { Pengaruh } \\
\text { Variabel }\end{array}$} & $\begin{array}{c}\text { Pengaruh } \\
\text { Langsung }\end{array}$ & $\begin{array}{c}\text { Pengaruh Tidak Langsung } \\
\text { (Melalui Profitabilitas) }\end{array}$ & $\begin{array}{c}\text { Pengaruh } \\
\text { Total }\end{array}$ \\
\hline DER $\rightarrow$ ROE & 0.471 & - & 0.471 \\
\hline KEPINST $\rightarrow$ ROE & -0.087 & - & -0.087 \\
\hline CR $\rightarrow$ ROE & 0.535 & - & 0.535 \\
\hline LNSIZE $\rightarrow$ ROE & -0.101 & - & -0.101 \\
\hline DER $\rightarrow$ PBV & 0.024 & 0.029 & 0.053 \\
\hline KEPINST $\rightarrow$ PBV & -0.003 & -0.005 & -0.008 \\
\hline CR $\rightarrow$ PBV & 0.006 & 0.033 & 0.039 \\
\hline LNSIZE $\rightarrow$ PBV & 0.025 & -0.006 & 0.019 \\
\hline ROE $\rightarrow$ PBV & 0.061 & - & 0.061 \\
\hline
\end{tabular}




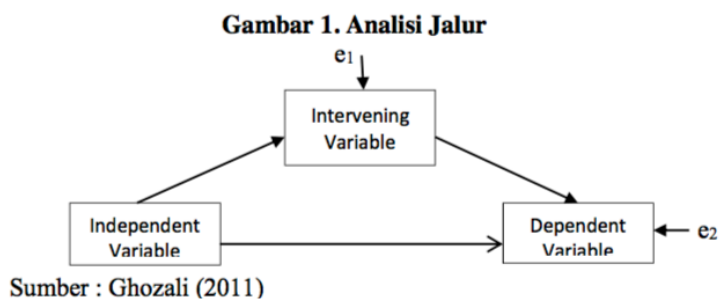

\begin{tabular}{|c|c|c|c|c|c|}
\hline \multicolumn{6}{|c|}{ Tabel 13. Sobel Test } \\
\hline & & & & t hitung & Hasil \\
\hline sb1b9 = & 0.006 & b1b9 = & 0.029 & 4.821 & Signifikan \\
\hline sb2b9 = & 0.003 & b2b9 = & -0.005 & -1.996 & tidak signifikan \\
\hline $\operatorname{sb} 3 b 9=$ & 0.023 & b3b9 = & 0.033 & 1.431 & tidak signifikan \\
\hline sb4b9 = & 0.004 & $b 4 b 9=$ & -0.006 & -1.465 & tidak signifikan \\
\hline
\end{tabular}

\section{PEMBAHASAN}

Hasil pengujian pada Tabel 11 menunjukkan Debt to Equity Ratio (DER) mempengaruhi secara positif signifikan terhadap ROE. ROE yang diperoleh dari perusahan dapat dipengaruhi oleh berapa besarnya nilai DER yang dimiliki perusahaan. Ketika biaya yang dikeluarkan dari hutang lebih rendah daripada dengan biaya dari modal sendiri, maka hutang dpat menjadi pilihan modal yang lebih tepat terkait dengan kemampuannya dalam mendapatkan laba (meningkatkan ROE) begitupun sebaliknya (Brigham, 1983), Mirza \& Javed (2013), Rub (2012) dan David \& Olorunfemi (2010) juga mengemukakan bahwa DER memiliki pengaruh yang positif signifikan terhadap ROE.

Hasil pengujian pada Tabel 11 menunjukkan kepemilikan institusi negatif signifikan dalam mempengaruhi ROE. Institutional Ownership ditemukan tidak memiliki pengaruh positif terhadap ROE, hal ini disebabkan karena kepemilikan institusi yang terlalu besar pada suatu perusahaan menyebabkan kurang optimalnya fungsi monitoring agents yang dilakukan oleh institusi, sehingga pengawasan yang dilakukan oleh pihak institusi tidak dapat membuat kemampuan perusahaan dalam penghasilkan laba menjadi meningkat. Hasil penelitian ini mendukung hasil penelitian dari Dehkalani et al, (2015) yang menyatakan bahwa kepemilikian institusi memiliki pengaruh yang negatif terhadap ROE.

Hasil pengujian pada Tabel 11 menunjukkan Current ratio dalam penelitian ini tidak memiliki pengaruh terhadap ROE. Penelitian ini mendukung penelitian yang telah lampau dari Putra \& Wiagustini (2013) dimana current ratio tidak mampu mempengaruhi ROE secara signifikan. Ukuran perusahaan dalam penelitian ini juga tidak memiliki pengaruh terhadap ROE. Hasil tersebut sesuai dengan hasil penelitian Hamid et al (2015) dan Shyu (2013) yang menyatakan bahwa ukuran perusahaan memiliki pengaruh negatif namum tidak signifikan terhadap ROE.

Hasil pengujian pada Tabel 12 menunjukkan bahwa Debt to Equity Ratio (DER) berpengaruh negatif terhadap Nilai Perusahaan. Hasil penelitian ini sesuai dengan pecking order theory yang mengunggulkan pemakaian modal sendiri (equity) untuk mendanai kebutuhan operasi dari perusahaan. Hasil penelitian ini sesuai dengan penelitian yang dilakukan oleh Hoque et al (2014), Loncan (2014) dan chen \& chen (2011) dimana nilai perusahaan dipengaruhi secara negative oleh DER.

Hasil pengujian pada Tabel 12 menunjukkan bahwa nilai perusahaan dipengaruhi secara signifikan positif oleh ownership institutional. Kepemilikan institusional yang besar dapat menjadikan fungsi pengawasan (monitoring) yang dilakukan oleh agents dalam hal ini adalah 
pemilik saham institusi menjadi meningkat sehingga pengambilan keputusan yang dilakukan oleh pihak manajemen dari perusahaan bisa lebih terkontrol dan menguntungkan berbagai pihak baik perusahaan maupun pemilik sahamnya. Apabila hal ini terjadi maka nilai dari perusahaan juga akan meningkat. Hasil penelitian ini didukung hasil penelitian dari Abukosim, (2014), Sukirni, (2012) dan Nuraina (2012) dimana kepemilikian institusi memiliki pengaruh yang positif terhadap Nilai Perusahaan. ROE juga memiliki pegaruh positif signifikan terhadap nilai perusahaan. Hasil penelitian ini sejalan dengan dengan teori signaling dimana informasi positif yang diberikan perusahaan kepada masyarakat akan menjadi sinyal yang akan diterima oleh para investor untuk memutuskan investasi. Salah satu informasi tersebut adalah mengenai tingkat profitabilitas perusahaan. Apabila profitabilitas meningkat maka nilai perusahaan juga akan mengalami peningkatan. Hasil penelitian ini didukung oleh penelitian dari Wijaya \& Linawati (2015), Hamidy dkk (2015), Mardiyati dkk (2012) dan Putra \& Wigiastuti (2013) yang menyatakn bahwa profitabilitas dalam hal ini diwakili oleh Return on Equity (ROE) mampu mempengaruhi secara positif signifikan terhadap nilai perusahaan.

Current ratio tidak memiliki pengaruh yang signifikan terhadap nilai perusahaan. Hasil tersbut didukung juga dengan hasil penelitian Putra \& Wiagustini (2013) dan Almudehki \& Zetun (2013) dimana likuiditas dalam hal ini diwakili oleh indicator current ratio tidak terbukti mempunyai pengaruh signifikan terhadap nilai perusahaan. Hasil pengujian juga menunjukkan bahwa ukuran perusahaan berpengaruh positif tidak signifikan terhadap nilai perusahaan. Hasil penelitian ini sesuai dengan hasil penelitian penelitian Nuraina (2012) dan Renders \& Gaeremynck (2012) yang menyatakan bahwa ukuran perusahaan berpengaruh positif terhadap nilai perusahaan.

Tabel 13 menunjukkan bahwa ROE dalam penelitian ini dinyatakan dapat menjadi variabel intervening dari pengaruh Debt to Equity ratio (DER) terhadap Nilai Perusahaan namun tidak mampu memediasi pengaruh kepemilikan institusi, current ratio dan ukuran perusahaan terhadap nilai perusahaan. Tabel 14 pada uji sobel juga menunjukkan bahwa ROE secara signifikan terbukti dapat memediasi pengaruh Debt to Equity ratio (DER) terhadap Nilai Perusahaan.

\section{SIMPULAN}

Return on equity dapat ditingkatkan dengan cara meningkatkan besarnya debt to equity ratio dan menurunkan besarnya kepemilikan institusi. Hal ini disebabkan karena debt to equity ratio berpengaruh positif signifikan terhadap Return on equity sedangkan kepemilikan institusi berpengaruh positif signifikan terhadap Return on equity. Nilai perusahaan dapat ditingkatkan dengan cara menurunkan besarnya debt to equity ratio dan menjadikan kepemilikan institusi meningkat serta Return on equity karena debt to equity ratio berpengaruh negatif signifikan terhadap nilai perusahaan sedangkan kepemilikan institusi serta Return on equity memiliki pengaruh yang positif signifikan terhadap nilai perusahaan. Return on equity sebagai variabel intervening mampu memediasi secara signifikan pengaruh Debt to Equity ratio (DER) terhadap Nilai Perusahaan namun tidak dapat memediasi pengaruh kepemilikan institusi, current ratio dan ukuran perusahaan terhadap nilai perusahaan.

Berdasarkan hasil penelitian yang telah dijelaskan di atas maka penelitian ini diharapkan dapat dijadikan sebagai referensi dalam mengambil keputusan terkait penentuan dalam memutuskan untuk memilih jenis investasi di pasar modal yaitu dalam proses membeli atau menjual saham. Selain itu bagi perusahaan emiten juga dapat menjadikan hasil penelitian ini sebagai bahan evaluasi perusahaan dalam memperbaiki kinerja keuangan perusahaan 
di masa yang akan datang dan juga agar perusahaan dapat lebih memperhatikan faktor-faktor yang dapat mempengaruhi nilai dari perusahaan, sehingga dari penelitian ini diharapkan dapat menambah ilmu, pengetahuan dan informasi dalam proses analisis investasi yang tepat.

Saran

Disarankan untuk penelitian yang akan datang dapat menmasukkan variabel lain di luar penelitian ini seperti kebijakan deviden, suku bunga, nilai tukar rupiah, inflasi, CSR, tingkat risiko bisnis dan tingkat risiko pasar yang dapat mempengaruhi Nilai Perusahaan. Selain itu peneliti juga dapat memperpanjang periode pengamatan dalam penelitian selanjutnya dan menggunakan sampel yang lebih spesifik lagi seperti subsektor yang ada di dalam industri manufaktur agar hasil penelitian yang diperoleh bisa lebih baik dan nilai adjusted $\mathrm{R}$ square yang diperoleh dalam penelitian selanjutnya bisa lebih tinggi dibandingkan pada penelitian ini.

\section{DAFTAR PUSTAKA}

Abukosim, et al. 2014. Ownership Structure And Firm Values: Empirical Study On Indonesia Manufacturing Listed Companies. International Refereed Research Journal, Vol.-V, Issue - 4, Oct. 2014 [1]

Almudehki, Noora \& Zeitun, Rami. 2013.Ownership Structure and Corporate Performance : Evidence from Qatar.

Ang, Robbert. 1997. Buku Pintar Pasar Modal Indonesia, Edisi 1, Mediasoft Indonesia.

Arouri, Houda, Hossain, Mohammed and Muttakin, Mohammad Badrul 2014, Effects of board and ownership structure on corporate performance: Evidence from GCC countries, Journal of Accounting in Emerging Economies, vol. 4, no. 1, pp. 117 $\square 130$

Brigham \& Houston. 2010. Dasar-Dasar Manajemn Keuangan: Essentials Of Financial Management edisi 11 (terjemahan). Cengange learning asia pte Itd diterjemahkan salemba empat : Jakarta.

Chen, L. J., \& Chen, S. Y. (2011). The influence of profitability on firm value with capital structure as the mediator and firm size and industry as moderators. Investment Management and Financial Innovations, 8(3), 121-129.

Cheung, W. M., Chung, R., \& Fung, S. (2015). The effects of stock liquidity on firm value and corporate governance: Endogeneity and the REIT experiment. Journal of Corporate Finance, 35, 211-231. http://doi.org/10.1016/j.jcorpfin.2015.09.001

Dehkalani, N. M., Asadi, A., \& Kordlouie, H. R. (2015). The Relationship between Institutional Ownership with the Current Financial, 2(5), 571-583.

Delen, D., Kuzey, C., \& Uyar, A. (2013). Measuring firm performance using financial ratios: A decision tree approach. Expert Systems with Applications, 40(10), 3970-3983. http://doi. org/10.1016/j.eswa.2013.01.012

Filatotchev, I., Zhang, X., \& Piesse, J. (2011). Multiple agency perspective, family control, and private information abuse in an emerging economy. Asia Pacific Journal of Management, 28 (1), 69-93.

Gamayuni, R. R. (2015). The Effect Of Intangible Asset, Financial Performance And Financial Policies On The Firm Value, 4(01), 202-212.

Hamid, M. A., Abdullah, A., \& Kamaruzzaman, N. A. (2015). Capital Structure and Profitability in Family and Non-Family Firms: Malaysian Evidence. Procedia Economics and Finance, 31(15), 44-55. http://doi.org/10.1016/S2212-5671(15)01130-2 
Hamidy, R. R., Wiksuana, I. G. B., Gede, L., \& Artini, S. (2015). Pengaruh Struktur Modal Terhadap Nilai Perusahaan Dengan Profitabilitas Sebagai Variabel Intervening Pada Perusahaan Properti dan Real Estate Di Bursa Efek Indonesia. E-journal Ekonomi dan Bisnis Universitas Udayana (Unud) 4.10, 665-682.

Hoque, Jahirul et al. 2014. Impact Of Capital Structure Policy On Value Of The Firm - A Study On Some Selected Corporate Manufacturing Firms Under Dhaka Stock Exchange. ECOFORUM, Volume 3, Issue 2 (5), 2014

Jensen, M. C., \& Meckling, W. H. (1976). Theory of the Firm : Managerial Behavior , Agency Costs and Ownership Structure Theory of the Firm : Managerial Behavior, Agency Costs and Ownership Structure. Journal of Financial Economics, 3(4), 305-360. http://doi.org/ http://dx.doi.org/10.1016/0304-405X(76)90026-X

Loncan, T. R., \& Caldeira, J. F. (2014). Capital Structure, Cash Holdings and Firm Value : a Study of Brazilian Listed Firms. Revista Contabilidade \& Finanças, 25(64), 46-59. http:// doi.org/10.2139/ssrn.2329346

Mahdaleta, E., Muda, I., \& Nasir, G. M. (2016). Effects of Capital Structure and Profitability on Corporate Value with Company Size as the Moderating Variable of Manufacturing Companies Listed on Indonesia Stock Exchange, 2(3), 30-43.

Mardiyati, U., Ahmad, G.N., \& Putri, R. 2012. Pengaruh Kebijakan Dividen, Kebijakan Hutang Dan Profitabilitas Terhadap Nilai Perusahaan Manufaktur Yang Terdaftar Di Bursa Efek Indonesia (Bei) Periode 2005- 2010. Jurnal Riset Manajemen Sains Indonesia (JRMSI) Vol. 3, No. 1, 2012

Mirza, S., \& Javed, A. (2013). Determinants of financial performance of a firm: Case of Pakistani stock market. Journal of Economics and International ..., 5(2), 43-52.

Norhayati, Mohamed; Wee Shu Hui; Normah Hj Omar; Rashidah Abdul Rahman; Norazam Mastuki; Mas Ainy Abdul Aziz; Dan Shazelina Zakaria, (2012), "Empirical Analysis Of Determinants On Dividend Payment : Profitability And Liquidity" Accounting Research Institute

Nuraina, E. (2012). Pengaruh Kepemilikan Institusional dan Ukuran Perusahaan terhadap Kebijakan Hutang dan Nilai Perusahaan. Jurnal Bisnis Dan Ekonomi, 19(2), 110-125.

Putra, Yudha D. \& Wiagustini, Ni Luh Putu. 2013. Pengaruh Likuiditas dan Leverage terhadap Profitabilitas dan Nilai Perusahaan pada Perusahaan Perbankan di BEl. Jurnal Wawasan Manajemen, Vol. 1, Nomer 2, Juni 2013.

Putu, et al. (2014). Factors Affecting Firms Value of Indonesia Public Manufacturing Firms. International Journal of Business and Management Invention ISSN (Online): 2319 - 8028, ISSN (Print): 2319 - 801X www.ijbmi.org Volume 3 Issue 2\|l February. 2014\| PP.35-44

Renders, Annelies and Gaeremynck, Ann. 2012. Corporate Governance, Principal- Principal Agency Conflicts, and Firm Value in European Listed Companies. Corporate Governance: An International Review, 2012, 20(2): 125-143

Rub, Nour Abu (2012), "Capital Structure And Firm Performance : Evidence From Palestine Stock Exchange" Journal Of Money, Investment And Banking

Shyu, J. (2013). Ownership structure, capital structure, and performance of group affiliation. Managerial Finance, 39(4), 404-420. http://doi.org/10.1108/03074351311306210

Sukirni, Dwi. 2012. Kepemilikan Manajerial, Kepemilikan Institusional, Kebijakan Deviden Dan Kebijakan Hutang Analisis Terhadap Nilai Perusahaan. Accounting Analysis Journal, 1 (2) (2012) ISSN 2252-6765Tahir, I. M., \& Razali, A. R. (2011). the Relationship Between Enterprise Risk Management (Erm) and Firm Value: Evidence From Malaysian Public Listed Companies. International Journal of Economics and Management Sciences, 1(2), $32-41$. 